renowned "Experiments on Magnesia Alba, etc.", in view of the author's occupancy for many years of the chair of chemistry in the University of Edinburgh. Succeeding reprints were: (2) "Foundations of the Atomic Theory", by Dalton, Wollaston and Thomson; (3) "Experiments on Air", by Cavendish; (4) "Foundations of the Molecular Theory", by Dalton, Gay-Lussac and Avogadro; (5) "Extracts from Micrographia", by Hooke; (6) "The Decomposition of the Alkalis and Alkaline Earths", by Davy ; (7) "The Discovery of Oxygen", Part I, by Priestley ; (8) "The Discovery of Oxygen", Part II, by Scheele; (9) "The Elementary Nature of Chlorine", by Davy ; (10) "Researches on the Arseniates, etc", by Graham ; (11) "Essays of Jean Rey" ; (12) "The Liquefaction of Gases", by Faraday ; (13) "The Early History of Chlorine", by Scheele and others ; (14) "The Molecular Asymmetry of Natural Organic Products", by Pasteur; (15) "The Electrolysis of Organic Compounds", by Kolbe ; (16) "Papers on Etherification, etc". by Williamson; (17) "MedicoPhysical Works", by Mayow ; (18) "Sketch of a Course of Chemical Philosophy", by Cannizzaro ; (19) "The Foundations of the Theory of Dilute Solutions", by Van't Hoff and Arrhenjus; (20) "Prout's Hypothesis", by Prout, Stas and Marignac; and (21) "On a New Chemical Theory, etc.", by Couper.

These twenty-one "Alembic Club Reprints" have enjoyed a steady sale (totalling more than 32,000 ) throughout the decades, and have undoubtedly proved of inestimable service to teachers, students and research workers in the domain of historical chemistry. They are issued by the Club's agents-E. and S. Livingstone, Teviot Place, Edinburgh - at a price just above the cost of publication, profits being deliberately restricted to a point that will permit the periodic replenishment of stock as particular numbers niear exhaustion. No. 17 only is now out of print, becauso of its special expense.

In the months immediately preceding his death, Dr. Dobbin - frail in body, but with mind alert and unimpaired-- became apprehensive as to the future of the Alembic Club, and the present secretary knew that he was acting as Dr. Dobbin himself would have desired when, with the approval of the other two surviving members, he proposed to the Council of the Royal Society of Edinburgh that the Council should accept the entire assets of the Club and the responsibility for the continuance of its series of reprints. This offer was cordially accepted by the Council on July 7,1952 , the general opinion being expressed that it would appear desirable not only to continue the existing reprints but also to extend the series by new issues of a similar nature in chemistry and adjoining fields of science. A committee was appointed, consisting of the president, the general secretary and the treasurer, to submit recommendations for the administration of the "Alembic Club Fund" on a broader and firmer basis under the ægis of the Royal Socjety of Edinburgh.

Before the Club passed under new management, however, its members decided to add to their number Norman Feather, professor of natural philosophy in the University of Edinburgh, in the hope that a precedent would thus be established ensuring the perpetuity of the Alembic Club within the Society.

The report of the Committee, approved by the Council on October 27, 1952, contained in fact a clause recommending that the Alembic Club should persist as a self-perpetuating body, fortified by the inclusion of the senior officers of the Society. Other recommendations were that an Alembic Club Prize of $£ 50$ should be awarded to a distinguished historian of science quinquennially, provided funds for it were sufficient, and that Alembic Club Lectures should be delivered at unspecified intervals. The first of such lectures will be formally entitled the Leonard Dobbin Memorial Lecture.

\section{INTERNATIONAL COUNCIL OF SCIENTIFIC UNIONS}

\section{GENERAL ASSEMBLY IN AMSTERDAM}

HE sixth general assembly of the International Council of Scientific Unions was held in the rooms of the Koninklijke Nederlandse Akademie van Wetenschappen in Amsterdam during October 1-3. Twenty countries were represented. Prof. H. R. Kruyt, president of the Division of Sciences of the Academy and a former president of the Council, welcomed the assembly on behalf of the Academy. He spoke of the importance of the work of the Unions with their freedom to organize scientific discussions unhampered by administrative and political influences, and pointed out that he has a special regard for the Council, having attended every meeting since 1922 .

The president of the Council, Prof. A. von Mura]t (Switzerland), thanked Prof. Kruyt for his welcome and the Netherlands Academy for its hospitality and help in arranging the meeting. He explained how his three years experience as president have given him a great respect for the Council and some of its activities; joint commissions, symposia, support of laboratories of international standing and of established scientific services, all are of great value at the present time. The Council owes a great debt to the United Nations Educational, Sciontific and Cultural Organization (Unesco) for its financial ajd, and it is glad to help the Organization to carry out part of its task ; Prof. Muralt also acknowledged the help given throughout by Prof. Pierre Auger (head of the Natural Sciences Division of Unesco) and his staff. International congresses have begun to grow too large, partly owing to the great increase in the number of scientific workers and the rapid growth of fresh branches of science, and the point is being reached where the present organization is becoming inadequate. One must not be too reluctant to see new Unions formed, but this must lead to difficulties in the co-ordination by a central body. There must come a time when some federal groups should be formed, intermediate between the Council and its individual Unions. He felt obliged to mention one activity of the Council, namely, the starting of an abstracting board to help in improving what has become in many sciences a difficult situation. A limit has been set at first to one subject - physies (see p. 954 of this issue). One result of improved co-ordination between existing abstracting journals has been a considerable speeding-up of the publication of abstracts.

After a tribute to the work of the Council and its Unions on the scientific side, Prof. Auger pointed out a gap between the purely scientific aspects and the financial and administrative ones. Those responsible for the latter side, he said, do not always understand the needs of those responsible for the former. One 
instance of this is the lack of sufficient representation of science in the national delegations to Unesco. Prof. Auger put forward a proposal, which would be followed up in 1953, to form a scientific advisory committee on international scientific problems, and he thought that this might fill the gap.

Four countries which had joined the International Council of Scientific Unions since the last general assembly were then welcomed by the president, namely, Israel, Thailand, Spain and the German Federal Republic.

The International Mathematical Union was admitted as a new adhering organization. It was reported that the executive board had accepted provisionally an application from the Union of Physiology, and had not accepted applications from International Unions of Biochemistry, Nutritional Sciences, Scientific Psychology, Scientific Study of Population, and Philosophy of Sciences. A discussion followed in the case of the Union of Biochemistry, and it was agreed to recommend the continuance of discussions between representatives of the Union and of the Section of Bjochemistry of the Union of Chemistry in the hope that an agreed solution of the problem might be found; a member of the Council would be ready to assist in these discussions as an independent observer?

Certain changes of statutes were made: these included the creation of the post of treasurer, to lighten the task of the general secretary; the removal of the figure of the annual contribution due from countries and unions from the statutes (power was given to the general assembly to fix it for three years at a time); and a tightening of the conditions governing the admission of newly formed Unions.

A discussion took place on the plans for an International Geophysical Year in 1957-58, a successor to the International Polar Years of 1882 and 1932. On this occasion observations would be made not merely in polar regions but also in low latitudes. The proposal came originally from the Joint Commission on the Ionosphere, but jt was supported by the Unions of Astronomy, Geodesy and Geophysics, Radio-Sciences, Physics and Geography; the World Meteorological Organization is also co-operating. A small co-ordinating committee has been formed and it will meet very shortly, its convener being Col. E. Herbays, general secretary of the International Scientific Radio Union. Countries adhering to the Council have been asked to form national committees which would carry out the programme once it has been formulated, and the steering committee will, in due course, be enlarged. Other countries outside the Council are also being approached. Proposals for a redetermination of the network of world longitudes in the year 1957-58 were referred to the committee for inclusion in the general scheme. There was general agreement that a few special problems should be tackled : this was better than an attempt to gather a mass of observational data. As an example, the morphology of magnetic and ionospheric storms was mentioned by Prof. Berkner as a suitable problem. The year 1957-58 was selected as being one near sunspot maximum.

The assembly decided to urge its national adhering bodies to press for greater scientific representation on the national delegations to Unesco, and it also asked delegates to press for support of two international agreements drawn up by Unesco, on the importation and on facilitation of circulation of educational, scientific and cultural materials.
It was agreed to sever connexion with the Committee on Science and Social Relations, which has become a Joint Commission with the International Council of Philosophy and Humanistic Studies. The interests of the Committee had tended to move over from the purely scientific to the human and social side. After a discussion on the activities of the International Abstracting Board, it was agreed that to avoid confusion it should be known as the "I.C.S.U. Abstracting Board" or the "Bureau des Résumés analytiques de C.U.I.S.".

Sir Harold Spencer Jones, the Astronomer Royal, expressed the thanks of the assembly to the president for his distinguished services-the grace, humour and firmness with which he had presided over their meetings during the past three years, and also to the retiring general secretary, Prof. F. J. M. Stratton (Great Britain) for his devoted labours on behalf of the Council over a period of fifteen years.

The bureau of the Council for the next three years was elected as follows: President, Prof. B. Lindblad (Sweden); Retiring President, Prof. A. von Muralt (Switzerland); Vice-Presidents, Prof. H. Solberg (Norway) and Col. E. Herbays (Belgium) ; Treasurer, Prof. W. Albert Noyes (United States) ; Secretary General, Prof. A. V. Hill (Great Britain); Members, I'rof. J. P'érès (France) and N. Kameyama (Japan).

\section{SEVENTEENTH INTERNATIONAL GEOGRAPHICAL CONGRESS, WASHINGTON, D.C.}

CINCE 1871 an International Geographical Con$\checkmark$ gress has been held normally every three or four years, during the past half-century under the auspices of a continuing body, the International Geographical Union. The seventeenth Congress was held in Washington, D.C., during August 7-16 and attracted a record number of approximately fifteen hundred participants. Of these, more than twelve hundred were in personal attendance, and despite the difficulties of travel and dollar shortages some five hundred delegates from overseas countries were present, including approximately fifty from Great Britain.

To enable visiting delegates to see as much as possible of the work of their American colleagues, a number of other meetings were arranged at convenient times.

This is the centenary year of the American Geographical Society in New York, and the Society held open house during August 4-6 at its delightful premises in Broadway at 156th Street. At a special meeting of the Society, visiting scientific workers were honoured, Mr. J. M. Wordie, president of St. John's College, Cambridge, and president of the Royal Geographical Society and leader of the British delegation, receiving the Daly Medal.

During August 6-7 the Association of American Geographers and the National Council of Geography Teachers met simultaneously in Washington, D.C., and their meetings and joint banquet were attended by many delegates.

The attendance of so many from overseas in the United States was made possible by a generous provision of travelling fellowships and grants, particularly from the Wallace W. Atwood Senior Fund, 